ks. Sławomir Płusa $a^{1}$

0000-0001-9297-124X

Katolicki Uniwersytet Lubelski Jana Pawła II

\title{
Przepowiadanie jako charyzmat. Chrzest w Duchu Świętym a głoszenie słowa Bożego
}

Posłuszeństwo Duchowi Świętemu, moc i autorytet, które On daje głoszącemu słowo, natchnienie w procesie przygotowania i głoszenia kazania czy homilii czynią z aktu komunikacji w procesie przepowiadania słowa Bożego akt zbawczy. Diagnoza stawiana dziś w odniesieniu do ewangelizacji - wielkie zadanie i wielkie zaniedbanie - rodzi pytania co do całej posługi głoszenia dziś i dotyczy w dużej mierze najpierw kaznodziei i jego serca, jego duchowości. Odnowienie wiary szafarzy słowa Bożego jest kluczem do udanej ewangelizacji. Chrzest w Duchu Świętym - fenomen mający swe źródło w Pięćdziesiątnicy Paschalnej - jest ważną drogą posoborowej odnowy Kościoła. Sobór Watykański II przypomniał, że cały Kościół ma naturę charyzmatyczną, tzn. prowadzi działalność uświęcającą nie tylko przez sakramenty i posługi, ale również

1 Ks. dr Sławomir Płusa - studiował pedagogikę i homiletykę w KUL (1992-1996), odbył studia doktoranckie z zakresu teologii pastoralnej i homiletyki w Wuerzburgu i Tybindze w Niemczech (1996-2001); związany z Odnową w Duchu Świętym i wspólnotami ewangelizacyjnymi.W swojej diecezji pełni posługę egzorcysty. E-mail: plusa.slawomir@gmail.com. 
przez charyzmaty². Kościół rośnie od środka i do środka³. „Kościół odmładza się - jak podkreśla Kongregacja Nauki Wiary w liście Iuvenscit Ecclesia - na mocy Ewangelii, a Duch Święty stale go odnawia, budując i prowadząc go poprzez rozmaite dary hierarchiczne i charyzmatyczne"4. Autentyczne charyzmaty należy postrzegać jako dary o niezbywalnym znaczeniu dla życia i misji Kościoła ${ }^{5}$. Wymiar charyzmatyczny Kościoła i jego konsekwencje dla przepowiadania słowa Bożego jest przedmiotem niniejszego artykułu.

\section{Duch Święty źródłem przepowiadania}

Święty Ireneusz uważa, że Kościół jest wsparty na dwóch kolumnach: Ewangelii i Ducha dającego życie ${ }^{6}$. Oprócz zewnętrznego głosu ludzkiego jest potrzebny głos wewnętrzny, głos Ducha Świętego. To temat, który jest bardzo bliski św. Augustynowi:

„Wasze uszy są dotknięte dźwiękiem moich słów, ale mistrz jest wewnętrzny. Możemy was pouczyć naszym głosem; lecz jeśli nie byłoby kogoś, kto by was pouczał od wewnątrz, to wydobywalibyśmy głos na próżno. [...] to w niebie znajduje się katedra Tego, który naucza we wnętrzu"7.

Raniero Cantalamessa podkreśla, że związek Ducha z przepowiadaniem słowa Bożego rozciąga się na wszystkie aspekty życia Kościoła:

Duch Święty:

Kładzie na ustach świętego pisarza słowo objawione i to jest Pismo święte.

Kładzie na ustach Kościoła słowa uwielbienia i to jest liturgia.

2 Por. Sobór Watykański II, Konstytucja dogmatyczna o Kościele „Lumen gentium”, w: Konstytucje. Dekrety. Deklaracje, Poznań 2002 (dalej: LG), nr 12.

3 Por. H. Mühlen, Kirche wächst von innen. Weg zu einer glaubensgeschichtlich neuen Gestalt der Kirche, Paderborn 1995, s. 175-178.

4 Kongregacja Nauki Wiary, List „Iuvenescit Ecclesia” na temat relacji między darami hierarchicznymi a charyzmatycznymi dla życia i misji Kościoła, nr 1, Rzym 2016, https://episkopat.pl/ en/relacja-miedzy-darami-hierarchicznymi-a-charyzmatycznymi-list-kongregacji-nauki-wiary (10.09.2018); por. LG, nr 4.

5 Por. Kongregacja Nauki Wiary, List „Iuvenescit Ecclesia”..., nr 9, dz. cyt.

6 Cyt. za: Y. Congar, Słowo i Tchnienie, Kraków 2018, s. 46 (Myśl Teologiczna, 94).

7 Cyt. za: Y. Congar, Słowo i Tchnienie, dz. cyt., s. 44. 
Kładzie na ustach Ojców słowa definicji i to jest dogmat.

Kładzie na ustach pasterzy słowa nauczania i to jest magisterium.

Kładzie na ustach kaznodziei słowo: „Jezus jest Panem!” i to jest ewangelizacja.

Kładzie na ustach kapłana słowa konsekracji i to jest Eucharystia.

Kładzie na ustach synów wołanie: „Abba, Ojcze!” i to jest modlitwa chrześcijańska.

Kładzie na ustach natchnionego słowo jak ogień i to jest proroctwo.

Kładzie na ustach wszystkich, którzy zasmakowali „młodego wina”, głosy radości

i to oznacza śpiewanie językami ${ }^{8}$.

Powyższy obraz aktywności Ducha Świętego w Kościele pokazuje, że głoszenie słowa Bożego jest przede wszystkim Jego darem. Niemiecki dogmatyk Heribert Mühlen zwraca uwagę na konieczność wzrostu duszpasterzy w postawie bycia obdarowanym przez Boga ${ }^{9}$. Ten sposób myślenia rozwija dziś, kontynuując myśl Benedykta XVI, papież Franciszek. W ewangelizacji, a także w innych formach przepowiadania słowa Bożego, obowiązuje zasada „prymatu łaski”, która mówi, że głoszenie słowa jest odpowiedzią na Bożą inicjatywę ${ }^{10}$.

Analiza tekstów biblijnych ukazuje istnienie ścisłego związku pomiędzy ruah i dabar. Dla autora Księgi Rodzaju są to dwie siły, które stwarzają świat (por. Ps 33,6) i porządkują go (por. Iz 11, 4). Prorocy są nazywani w Biblii raz ludźmi słowa, a innym razem ludźmi Ducha ${ }^{11}$. Słowo i Tchnienie, słowo i Duch - zależność ta jest widoczna zarówno w odniesieniu do natchnienia biblijnego, jak i do proroctwa ${ }^{12}$. Ciekawym przykładem jest tu fragment 2. Listu do Tymoteusza $(3,16)$. Użyte przez św. Pawła słowo theopneustos jest tłumaczone zazwyczaj w stronie biernej: „wszelkie Pismo od Boga natchnione". Tymczasem w tekście oryginalnym jest użyty imiesłów w stronie czynnej i dlatego zdanie to należałoby przetłumaczyć jako „wszelkie Pismo tchnące Bogiem”13. Pomiędzy natchnionym

8 R. Cantalamessa, Pieśń Ducha Świętego. Rozważania na temat „Veni Creator”, Warszawa 2003, s. 283-284.

9 Por. H. Mühlen, Kirche wächst von innen, dz. cyt., s. 178.

10 Por. Franciszek, Adhortacja apostolska „Evangelii gaudium” o głoszeniu Ewangelii we wspótczesnym świecie, Kraków 2013 (dalej: EG), nr 113.

11 Ta wzajemność ma korzeń trynitarny, Duch przychodzi bowiem „przez” Syna, ale równocześnie Syn zostaje zrodzony „w” Duchu. Por. W. P. Chlondowski, Spełniona obietnica. Kim jest i jak działa Duch Święty?, Cieszyn [2016], s. 229.

12 Por. Y. Congar, Słowo i Tchnienie, dz. cyt., s. 34-35.

13 Por. Y. Congar, Słowo i Tchnienie, dz. cyt., s. 34-35. 
słowem w ustach ludzi i kartach Biblii istnieje więc głęboka zależność. Oto ludzie kierowani przez Ducha Świętego - jak chce 1 P 1, 21 - głoszą słowa proroctwa, a następnie to samo słowo Pisma Świętego, kiedy jest czytane z wiarą, przekazuje Ducha. Natchnione przez Ducha staje się tchnące Duchem. Duch jest tym, który daje słowo Boże i który równolegle $\mathrm{w}$ tym słowie jest dawany ${ }^{14}$.

Między głoszącymi słowo uczniami Jezusa a Dawcą daru słowa istnieje więc ścisła relacja przynależności i zależności. To nie uczniowie mówią, lecz Duch. Niemniej Duch Święty potrzebuje ust uczniów i ich woli. Oni muszą chcieć mówić, aby Duch doszedł do głosu. Duch daje nie tylko słowa, ale ich artykulację, sposób mówienia i przyszłość słowa. To słowo staje się słowem samego Chrystusa (por. Kol 1, 27) ${ }^{15}$, dlatego, zdaniem Cantalamessy, Dobrą Nowinę można głosić tylko „w Duchu Świętym”"

\section{Fenomen chrztu w Duchu Świętym}

W niedzielę Zielonych Świąt w 2008 papież Benedykt wypowiedział następujące słowa:

Dziś chcę do tego zachęcić wszystkich: odkrywajmy, drodzy bracia i siostry, jak pięknie jest otrzymać chrzest w Duchu Świętym; uświadamiajmy sobie, że nasz chrzest i bierzmowanie są niewyczerpanym źródłem łaski. Prośmy Najświętszą Maryję Pannę, by wyjednała dla Kościoła także dziś nową Pięćdziesiątnicę, która pozwoli wszystkim, a zwłaszcza młodzieży, z radością żyć i dawać świadectwo Ewangelii ${ }^{17}$.

W powyższej wypowiedzi papieskiej pojawia się pojęcie chrztu w Duchu Świętym połączone z bardzo krótkim objaśnieniem, że trzeba je interpretować jako odnowienie świadomości mocy sakramentów chrztu i bierzmowania. W tym kontekście należy również widzieć,

14 Por. Y. Congar, Słowo i Tchnienie, dz. cyt., s. 34-35.

15 Por. R. Bohren, Predigtlehre, München 1971, s. 83-84.

16 Por. R. Cantalamessa, Tajemnica Pięćdziesiątnicy, Wrocław 2002, s. 37.

17 Benedykt XVI, Rozważanie na „Anioł Pański” (11.05.2008), cyt. za: Międzynarodowe Służby Katolickiej Odnowy Charyzmatycznej. Komisja Doktrynalna, Chrzest w Duchu Świętym, Kraków 2014, s. 7. 
że „ochrzczenie wyznawców Chrystusa Duchem Świętym” łączy się ściśle $\mathrm{z}$ „namaszczeniem Jezusa” i wyraża jedność Głowy i Ciała ${ }^{18}$.

\section{a) Teologia chrztu w Duchu Świętym}

Pojęcie chrztu w Duchu Świętym powoli wchodzi na stałe do refleksji i języka teologii katolickiej. Podejmowane są studia biblijne i dogmatyczne co do jego relacji do sakramentów chrztu i bierzmowania ${ }^{19}$. Najkrótszy opis tego doświadczenia, sięgający korzeniami św. Augustyna, brzmi: aktualizacja poprzednio udzielonej łaski ${ }^{20}$. W oparciu o studium tekstów biblijnych i patrystycznych Kilian McDonnell oraz George T. Montague dochodzą do wniosku, że chrzest w Duchu Świętym jest integralną częścią inicjacji chrześcijańskiej i należy nie do prywatnej pobożności, ale do liturgii publicznej i do oficjalnego kultu Kościoła. Z tego powodu nie jest to łaska dla nielicznych, ale wspólny dar dla wszystkich ${ }^{21}$. Cantalamessa wyjaśnia pozorną sprzeczność pomiędzy obecnością Ducha Świętego w Kościele a prośbą, by znów przyszedł, posługując się teologią św. Tomasza z Akwinu. Doktor Anielski wyjaśnia, że Paraklet nie przychodzi w formie przemieszczania się z miejsca, gdzie jest, do miejsca, gdzie go nie było. Każde nowe przyjście Ducha Świętego oznacza Jego zaistnienie w nowy sposób w tych, których czyni świątynią Boga ${ }^{22}$.

„Spełnia się niewidzialna misja Ducha za każdym razem, gdy realizuje się postęp w cnocie albo wzrost łaski - twierdzi Tomasz z Akwinu - [...]; kiedy ktoś przechodzi do nowej działalności lub do nowego stanu łaski: na przykład, gdy otrzymuje łaskę sprawiania cudów czy dar proroctwa, kiedy pobudzony żarem miłości wydaje się na męczeństwo, albo gdy

18 Por. W. Chrostowski, Biblijna nauka o Duchu Świętym, w: Jesteśmy napełnieni Duchem Świętym: zeszyt teologiczno-pastoralny, red. J. Bartoszek, R. Chromy, K. Piechaczek, Katowice 2017, s. 54-55 (Program duszpasterski Kościoła w Polsce na Rok 2017-2018, 4).

19 Zob. M. Bigiel, Jezus chrzci Duchem Świętym, Łódź 1997.

20 Por. J. Kudasiewicz, Odkrywanie Ducha Świętego. Medytacje biblijne, Kielce 1998, s. 387.

21 Por. K. McDonnell, G. T. Montague, Inicjacja chrześcijańska a chrzest w Duchu Świętym. Świadectwo z pierwszych ośmiu wieków, Kraków 1997, s. 445.

22 Por. R. Cantalamessa, Tajemnica Pięćdziesiątnicy, dz. cyt., s. 78. 
wyrzeka się własnych dóbr lub podejmuje jakąkolwiek inną rzecz, śmiałą i angażującą"

Chrzest w Duchu Świętym jest jednym z przejawów takiego właśnie działania. Jest to nie tylko odnowienie i aktualizacja sakramentu chrztu, ale całego chrześcijańskiego wtajemniczenia. W dzisiejszej praktyce duszpasterskiej proces ten może obejmować kilka lub kilkanaście spotkań formacyjnych; czasem ujawnia się spontanicznie poza wszelkimi schematami ${ }^{24}$.

Dokument Komisji Doktrynalnej Katolickiej Odnowy Charyzmatycznej na temat chrztu w Duchu Świętym wylicza następujące jego cechy: nowa świadomość rzeczywistości i obecności Boga, moc uświęcenia, uzdolnienie do uwielbienia, odkrycie mocy modlitwy, Pisma Świętego i sakramentów, otwartość na charyzmaty, posługa uzdrowienia i uwolnienia, mobilizacja świeckich do odpowiedzialności za Kościół, ewangelizacja, zaangażowanie w sprawę sprawiedliwości społecznej, zryw ekumeniczny, nowe wspólnoty ${ }^{25}$. Odsłania się w ten sposób charyzmatyczna struktura Kościoła, bez której nie jest możliwa ewangelizacja, przepowiadanie słowa Bożego i jakiekolwiek apostolstwo. Duch Święty staje się widzialny za pośrednictwem różnorodnych posług ${ }^{26}$.

Nowe wylanie Ducha Świętego jest możliwe i konieczne w każdej epoce. Charakterystyka chrztu w Duchu Świętym pokazuje, że nie jest on zjawiskiem marginalnym w życiu chrześcijanina. Dotyczy on istoty Ewangelii, misji Syna Bożego i Ducha Świętego, którą otrzymują od Ojca ${ }^{27}$. Ten rodzaj doświadczenia chrześcijańskiego ma bardzo silne oddziaływanie na postawę duchową chrześcijanina, co nie pozostaje bez wpływu na nadawcę i odbiorcę słowa Bożego w procesie jego głoszenia.

${ }^{23}$ Tomasz z Akwinu, Komentarz do Ewangelii Jana, XV, nr 2061. Cyt. za: R. Cantalamessa, Tajemnica Pięćdziesiątnicy, dz. cyt., s. 78.

24 Por. R. Cantalamessa, Tajemnica Pięćdziesiatnicy, dz. cyt., s. 79.

25 Por. Międzynarodowe Służby Katolickiej Odnowy Charyzmatycznej. Komisja Doktrynalna, Chrzest w Duchu Świętym, dz. cyt., s. 14-24.

26 Odnowa Charyzmatyczna. Wskazania teologiczne i duszpasterskie, I. Dokument z Malines, red. L. J. Suenens, Kraków 2006, s. 29-30.

27 Por. Odnowa Charyzmatyczna. Wskazania teologiczne i duszpasterskie, dz. cyt., s. 58. 
b) Wydarzenie pentekostalne w Duquesne

Dla całości obrazu konieczne jest jeszcze dopowiedzenie historyczne. W Kościele rzymskokatolickim doświadczenie chrztu w Duchu Świętym zaczęło się upowszechniać na masową skalę od lutego 1967 roku. Kilku pracowników i studentów Uniwersytetu Ducha Świętego w Pittsburgu przeżywało wówczas swoje weekendowe rekolekcje. Pod wpływem tego, co działo w ruchach zielonoświątkowych oraz w niektórych tradycyjnych wspólnotach protestanckich, modlili się gorąco, by przyszedł do nich Duch Święty, by odnowił w nich moc chrztu i bierzmowania. Zapragnęli, by działanie Ducha przeniknęło całe ich życie. Podczas śpiewu hymnu Veni Creator Spiritus doświadczyli spektakularnego wylania Ducha Świętego, który przyszedł do nich z darem języków, proroctwa i innymi charyzmatami ${ }^{28}$. Ten moment uznaje się za narodziny Katolickiej Odnowy Charyzmatycznej. Odnowienie wiary poprzez doświadczenie chrztu w Duchu Świętym rozlało się na cały świat. Szacuje się, że Katolicka Odnowa Charyzmatyczna dotarła do ok. 240 krajów i ogarnia ponad $120 \mathrm{mln}$ katolików ${ }^{29}$. Fenomen pentekostalizmu, który zrodził się w różnych denominacjach chrześcijańskich oraz w Kościołach tradycyjnych, jest ruchem duchowym o największej skali w całej dotychczasowej historii Kościoła ${ }^{30}$. Wśród promotorów Katolickiej Odnowy w Duchu Świętym panuje przekonanie, że nie chodzi w niej o nową instytucję, organizację czy stowarzyszenie świeckich; jest to przede wszystkim poruszenie płynące od Ducha Świętego do całego Kościoła, to wylanie łaski na każde$\mathrm{go}^{31}$. Zamysł Boży odnośnie do przekazywania chrześcijanom doświadczenia chrztu w Duchu Świętym jest taki, by cały Kościół odnawiał się w mocy w Ducha Świętego, tzn. by sięgał bardziej radykalnie do źródła

28 Por. Międzynarodowe Służby Katolickiej Odnowy Charyzmatycznej. Komisja Doktrynalna, Chrzest w Duchu Świętym, dz. cyt., s. 8.

${ }_{29}$ Por. Międzynarodowe Służby Katolickiej Odnowy Charyzmatycznej. Komisja Doktrynalna, Chrzest w Duchu Świętym, dz. cyt., s. 8.

30 Por. R. Cantalamessa, Pieśń Ducha Świętego, dz. cyt., s. 78.

31 Por. R. Faricy, The Baptism in the Holy Spirit: My experience and a conclusion, w: Charism and the Charismatic Renewel in the Catholic Church. International Colloquium (Rome, 3-6 April 2008), Vatican 2015, s. 77. 
swojej tożsamości i misji. Odnowa w Duchu Świętym Kościoła jest więc szczególną drogą realizacji soborowej zasady: Ecclesia semper reformanda.

\section{Chrzest w Duchu Świętym a duchowość kaznodziei}

Gdy Duch Święty staje się rzeczywistym źródłem w życiu duchowym kaznodziei, objawia się to w wielorakim i wielopoziomowym oddziaływaniem na kaznodzieję. Jego skutki w oczywisty sposób widać m.in. na etapie przygotowania homilii, kazania czy konferencji. Zażyłość z Duchem Świętym staje się dla kaznodziei źródłem dynamizmu i mocy w głoszeniu słowa Bożego.

Zdaniem Cantalamessy, wpływ Ducha Świętego na postawę duchową kaznodziei wyraża się najpierw w odkryciu i przyjęciu Bożej mocy oraz w uwolnieniu od pustki. Biblijny klucz od odkrycia znaczenia tych darów zawarty jest w określeniu „święty” (qadosh). Termin w swoim pierwotnym znaczeniu nie odnosi się do sfery moralnej, lecz do siły i potęgi Boga. Pojęcie „święty” jest kojarzone nawet ze słowem „straszliwy” (Ps 111, 9). Tak rozumiane pojęcie „święty” zostało przypisane Bożemu Duchowi i jest Jego wyjątkowym atrybutem. Podobny obraz Ducha Świętego przekazuje nam również Nowy Testament. Jezus powraca po chrzcie w Jordanie „w mocy Ducha” (Łk 4, 14); jest to „moc Najwyższego” (Łk 1, 15). Zesłanie Ducha w dniu Pięćdziesiątnicy zostaje nieprzypadkowo opisane przy pomocy tych samych pojęć, które są użyte w opisie teofanii na górze Synaj (zob. Wj 19-20). Uwzględnienie tej rzeczywistości w praktyce życia duchowego oznacza, że jedyną prawdziwą mocą, jedyną władzą podtrzymującą Kościół, jest Duch Święty. Św. Paweł odnosi to do skutecznego głoszenia słowa Bożego i stwierdza w 1 Liście do Tesaloniczan $(1,5)$ : „Bo nasze głoszenie Ewangelii wśród was nie dokonało się przez samo tylko słowo, lecz przez moc i przez Ducha Świętego, z wielką siłą przekonania". Tylko w Duchu Świętym Kościół i każdy głosiciel słowa Bożego mają władzę przekonywania i nawracania, przenikania do serca kultur i obalania twierdz wzniesionych w nich przeciwko Chrystusowi ${ }^{32}$.

32 Por. R. Cantalamessa, Pieśń Ducha Świętego, dz. cyt., s. 28-29. 
Taka moc Ducha promieniuje następnie na decyzje człowieka i wspiera jego moralną świętość. Słabość człowieka niejako prowokuje Ducha do działania i objawiania swej mocy. Ludzka samotność natomiast może się stać okazją do doświadczenia działania „słodkiego Gościa”, „doskonałego Pocieszyciela”, „cudownego Doradcy”33. W sytuacji samotności kaznodziei wobec misji głoszenia słowa przyjęcie tego rodzaju działania Ducha jest wyzwalające i uzdrawiające. Właśnie w tej „pracy” Duch daje „ochłodę”, jak pokazuje to hymn Veni Creator Spiritus.

Dla duchowego profilu kaznodziei kluczowe znaczenie ma też uwolnienie od grzechu i letniości. Zapowiedź Jana: „On chrzcić was będzie Duchem Świętym i ogniem” (Mt 3, 11) oznacza, że Duch Święty jest tym, który oczyszcza człowieka w jego głębi, kruszy serce z kamienia, niszczy „ciało grzechu” (Rz 6, 6) i odbudowuje obraz Boży ${ }^{34}$. Kościół jest miejscem, gdzie „płonie” Duch Święty i unicestwia śmieci w duszy. Błogosławiony jest ten nadawca i odbiorca słowa Bożego, który dom swego serca otworzy na ten płomień ukryty we wnętrzu Kościoła ${ }^{35}$.

Chrzest w Duchu Świętym to ochrzczenie miłością, którą wzbudza Duch Święty. On daje On łaskę trzeźwego upojenia, które, zdaniem Cyryla Jerozolimskiego, uśmierca grzechy i ożywia serce ${ }^{36}$. Tu rodzi się moc słowa, które może ożywiać najpierw serce samego kaznodziei, a następnie jego odbiorców. Z „dotyku palcem Bożym”, jakim jest działanie Ducha Świętego, bierze początek ta sama „moc” i ,autorytet”, które emanowały ze słów i czynów Chrystusa - kiedy On mówił lub coś czynił, cierpiący byli pocieszani, więźniowie uwalniani. Nie były to tylko słowa, lecz była w nich moc Ducha Bożego. Również dzisiaj ta sama moc jest podarowana Kościołowi. Jest ona źródłem nadprzyrodzonej skuteczności dla służby słowem podejmowanej dla Bożego królestwa ${ }^{37}$. Ci, którzy spełniają posługę, winni ją wypełniać nie własną energią, ale tą, której udziela sam Bóg ${ }^{38}$.

\footnotetext{
Por. R. Cantalamessa, Pieśń Ducha Świętego, dz. cyt., s. 35.

Por. R. Cantalamessa, Pieśń Ducha Świętego, dz. cyt., s. 150.

Por. R. Cantalamessa, Pieśń Ducha Świętego, dz. cyt., s. 154.

Por. R. Cantalamessa, Pieśń Ducha Świętego, dz. cyt., s. 183.

Por. R. Cantalamessa, Pieśń Ducha Świętego, dz. cyt., s. 249-250.

Por. R. Cantalamessa, Pieśń Ducha Świętego, dz. cyt., s. 251.
} 
Godnym podkreślenia jest też fakt, że owocem zanurzenia w moc Ducha Świętego jest uwolnienie od lęku. Dzieje się tak ponieważ działa On w głębi ludzkiego serca i woła: Abba. Przekonuje naszego ducha, że jesteśmy dziećmi Bożymi (Rz 8, 16). Wraz z nadejściem łaski Chrystusa Bóg nie ogranicza się do powiedzenia człowiekowi, że ten ma coś czynić lub nie, ale czyni to wraz z człowiekiem. Co więcej, On walczy za nas ${ }^{39}$ ! Dla owocności przepowiadania słowa Bożego i wolności wewnętrznej kaznodziei ma to kluczowe znaczenie.

Szczególnym mieczem Ducha jest słowo Boże ${ }^{40}$. Doświadczenie wiary, postawa duchowa kaznodziei jest tu jednym z ważnych kluczy dla uobecnienia tej mocy. To On daje moc przepowiadaniu. Kaznodzieja ubogacony charyzmatami Ducha Świętego dokonuje interpretacji rzeczywistości w świetle słowa, rozeznaje i rozróżnia duchy, odsłania to, co Duch Święty mówi w jakiejś konkretnej sytuacji. Duch Święty uczy głosić Jezusa jako „Pana”41. Dlatego szczególnego znaczenia dla kaznodziei nabiera głoszenie kerygmatu. Zdaniem papieża Franciszka kerygma jest ogniem Ducha Świętego ${ }^{42}$.

\section{Charyzmaty słowa a przepowiadanie słowa Bożego}

Związek ruach ze słowem wydaje się być kluczowy dla odkrycia mocy przepowiadania w Kościele. Cantalamessa uważa, że w dzień Pięćdziesiątnicy ujawniło się szereg charyzmatów związanych ze słowem: mówienie językami, proroctwo, dar przepowiadania narodom, dar wielbienia Boga. Również dziś Duch Święty chce obdarowywać charyzmatami dla większej skuteczności posługi słowem. Duch Święty jest w nas wewnętrznym Nauczycielem ${ }^{43}$. Słowo Boże głoszone przez człowieka dopiero wtedy owocuje, gdy zacznie działać ten Nauczyciel, który jest w sercu. Tę funkcję nauczycielską Ducha Świętego potwierdzają dary i charyzmaty.

\footnotetext{
39 Por. R. Cantalamessa, Pieśń Ducha Świętego, dz. cyt., s. 365.

40 Por. R. Cantalamessa, Pieśń Ducha Świętego, dz. cyt., s. 367.

41 Por. R. Cantalamessa, Pieśń Ducha Świętego, dz. cyt., s. 410.

42 Por. EG 164.

43 J. Kudasiewicz, Duch Święty i Jego dary, dz. cyt., s. 19-22.
} 
Pierwsze trzy dary odnoszą się do umysłu człowieka: mądrość, rozum, rada. W pierwszym katalogu charyzmatów św. Paweł wymienia mądrość słowa i umiejętność poznania. Dary i charyzmaty próbują ogarnąć rzeczywistość całego człowieka.

Zdanie: „sermone ditans guttura” z hymnu Rabana Maura Veni Creator Spiritus, które znamy z tłumaczenia: „Mową wzbogacasz język nasz” (3. zwrotka), Cantalamessa oddaje inaczej: „Ty słowem ubogacasz usta”. Kładzenie przez Boga na czyichś ustach słowa, oznacza w Biblii najpierw przejaw charyzmatu proroctwa. W ten sposób jest scharakteryzowany następca Mojżesza, powołanie Izajasza i uzdolnienie do misji Jeremiasza. Możliwe jest też odniesienie do Jezusowej obietnicy, że Duch Święty uzdolni Jego uczniów do dawania świadectwa, dzięki natchnionej wymowie i mądrości, której nie będzie mógł się przeciwstawićc ${ }^{44}$.

Umocnienie ludzkich słów ogniem Ducha jest konieczne dla głosiciela słowa i dla każdego wierzącego. Słowa w ustach chrześcijanina moga mieć logiczny sens, ale będą pozbawione mocy, zgodnie z tym, jak ujmuje to ewangelista Mateusz: „Wiedzcie, że w dniu sądu ludzie zdadzą sprawę z każdego niepotrzebnego słowa" (por. Mt 12,36). W świetle miejsca paralelnego (por. Mt 7, 15-20) narzuca się wniosek, że przymiotnik argon powinien być tłumaczony w formie aktywnej - nieskuteczne, nic niebudujące, nic niesprawiające. Tak więc argon to słowa fałszywych proroków, które są przeciwieństwem słowa Bożego - energes, które jest zawsze skuteczne (por. Hbr 4, 12; 1 Tes 2,13). Nieskuteczność słów, z których każdy będzie musiał zdać sprawę, nie polega na np. wielomówstwie czy gadaninie bez sensu, lecz odnosi się do słów zamkniętych na moc Boga, pozbawionych natchnienia Ducha. Fałszywi prorocy czerpią z własnych serc, a nie z Serca Boga; w wypowiadanych słowach szukają własnej chwały, a nie Bożej; chcą podziwu i afirmacji ze strony ludzi dla siebie (i dlatego mogą wpadać w gadulstwo); nie rozpala ich pragnienie Ducha, aby wszyscy poznali jedynego prawdziwego Boga-Jezusa Chrystusa (por.J 17, 4) ${ }^{45}$.

Cechą charakterystyczną dla charyzmatów języka jest to, że decyzja człowieka oddania się Duchowi Świętemu do dyspozycji owocuje

\footnotetext{
${ }^{44}$ Por. W. Chlondowski, Spetniona obietnica, dz. cyt., s. 230.

${ }^{45}$ Por. W. Chlondowski, Spetniona obietnica, dz. cyt., s. 231.
} 
porwaniem jego serca przez słowo, które daje mu Duch. Paraklet, szanując ludzką wolę, nigdy nie działa, zniewalając. Posługuje się jednak swoistym przynagleniem, które znacząco wpływa na głoszenie słowa. Może to dotyczyć słowa prorockiego skierowanego do konkretnych ludzi, proroctwa w językach, fragmentu nauczania czy posługi w konfesjonale ${ }^{46}$.

Proroctwo pochodzi od Ducha Świętego i jest natchnioną, zrozumiałą mową daną dla pożytku prorokującego; nie jest sprawnością, której można się nauczyć. Jest to mowa natchniona ${ }^{47}$. W odróżnieniu do ST w NT już nie ma zapowiedzi przyszłego zbawienia, lecz jest wskazanie na realną, choć ukrytą obecność Mesjasza w świecie. Nową treścią proroctwa jest osoba Jezusa Chrystusa. „Rozpoznanie i obwieszczenie w Duchu Chrystusa obecnego w świecie - według Cantalamessy - jest właśnie istotą proroctwa chrześcijańskiego" ${ }^{48}$. Proroctwa w Kościele dotyczą więc przede wszystkim teraźniejszości, a nie przyszłości. Charyzmat ten odnosi się do wszystkich wierzących i dlatego Kościół może być nazwany ludem prorockim. Przez słowa i czyny chrześcijan Duch dokonuje swojego samoobjawienia. Prorok ma dawać świadectwo o Jezusie. Jest też odwrotny kierunek - dawanie świadectwa o Jezusie czyni z człowieka, w pewnym sensie, proroka ${ }^{49}$.

Charyzmat proroctwa jest konieczny w życiu osób duchownych i świeckich. Jest bardzo potrzebny również na ambonie. Pośród charyzmatów opisywanych przez Pawła i Łukasza proroctwo zajmuje szczególne miejsce (por. 1 Kor 14, 4-5), gdyż przez nie Duch Święty sposób buduje Kościół, zachęca i pociesza wierzących, ujawnia zamysły serc. Aby widzieć prorokowanie w sposób zrównoważony, należy, zdaniem Andrzeja Sionka, odnosić je do głoszenia kerygmatu w coraz to nowych uwarunkowaniach historycznych. Święty Paweł odróżnia zdecydowanie kerygmat od proroctwa. O ile w kerygmacie głosimy jednorazowy Boży akt zbawczy, o tyle proroctwo ożywia objawienie Chrystusa i czyni je aktualnym w konkretnym kontekście. Dla św. Pawła wspólnota bez głoszonego

${ }^{46}$ Por. W. Chlondowski, Spełniona obietnica, dz. cyt., s. 232.

47 Por. A. Sionek, Charyzmaty. Aktywna obecność Boga w Kościele, Kraków 2017, s. 69.

48 R. Cantalamessa, Raduj się, Córko Syjonu. Tajemnica Bożego Narodzenia, Warszawa 1995, s. 66. Por. W. P. Chlondowski, Spełniona obietnica, dz. cyt., s. 238.

49 Por. W. P. Chlondowski, Spetniona obietnica, dz. cyt., s. 239. 
i strzeżonego kerygmatu oraz bez ubiegania się o stale nowe objawienie prorockie nie ma przyszłości ${ }^{50}$.

Ubogacenie przez Ducha Świętego ust głoszącego słowem Beda Czcigodny rozciągał również na dar nauczania. Jego zdaniem, ci którzy otrzymali ognisty język, rozjaśniają umysł bliźniego, sprawiając, że Chrystus rozbrzmiewa między nimi ${ }^{51}$. O ile proroctwo podsuwa nowe słowa Boga, to charyzmat nauczania (Rz 12, 6-7) oznacza umiejętność uchwycenia nowych zastosowań Objawienia podarowanego nam już w słowie Bożym. Taki charyzmat posiadali Ojcowie Kościoła, którzy w tekstach ST i NT wciąż odnajdywali nowe treści potrzebne do duchowego wzrostu wiernych ${ }^{52}$. Charyzmat nauczania daje głosicielowi Ewangelii charakterystyczny duchowy autorytet, objawiający się w trakcie głoszenia. „Może on polegać na doświadczeniu przez głoszącego pewnego wzruszenia, siły lub przekonania, niepochodzącego od niego, a które 'nakłada się' na jego słowa i sprawia, że jego mowa jest mocna i jaśniejsza. To jest to samo doświadczenie, którego świadkami byli słuchacze apostołów: „Głosiliśmy wam bowiem Ewangelię nie tylko słowem, ale w mocy Ducha Świętego i z pełnym przekonaniem" (1 Tes 1, 5; por. 1 Kor 2, 4-5). W ten sposób ukazuje się niezwykła skuteczność słów namaszczonych przez Parakleta" ${ }^{53}$.

\section{Zakończenie}

Powszechne wylanie Ducha Świętego i hojność w udzielaniu charyzmatów przez Ducha Świętego w naszych czasach jest dla wielu kaznodziejów nadal zbyt słabo znanym źródłem. Chrzest w Duchu Świętym uzdalnia do głębokiego przeżywania każdej Eucharystii jako fascynującego misterium. Józef Kudasiewicz proponuje, by homilia jako część tego misterium opierała się nie tylko na tekstach biblijnych, ale również

50 Por. A. Sionek, Napetniajcie się Duchem! Wspótczesny etos Nowej Ewangelizacji, Kraków 2018, s. 23.

51 Cyt. za: R. Cantalamessa, Pieśń Ducha Świętego, dz. cyt., s. 272.

52 Por. R. Cantalamessa, Pieśń Ducha Świętego, dz. cyt., s. 241.

53 R. Cantalamessa, Pieśń Ducha Świętego, dz. cyt., s. 242. 
na tekstach liturgicznych. Na przykład w epiklezie komunijnej celebrans prosi, żeby lud został napełniony Duchem Świętym, ale wierni o tym nie wiedzą.

Homilista nie powinien się też bać osobistego świadectwa ${ }^{54}$. Obok homilii częścią niedzielnej liturgii może być świadectwo osób, które doświadczyły chrztu w Duchu Świętym. W ten sposób każda niedziela może być przeżywana jak czas nowych Zielonych Świąt ${ }^{55}$.

Skoro chrzest w Duchu Świętym nie jest opcją, lecz istotnym elementem inicjacji chrześcijańskiej, szczególne miejsce w głoszeniu słowa Bożego powinno mieć przepowiadanie kerygmatyczne, które odsłania bezwarunkową miłość Boga Ojca do swego stworzenia, misterium zbawienia w Jezusie Chrystusie, Synu Bożym oraz moc Ducha Świętego działającego dziś, zwłaszcza w Kościele ${ }^{56}$. Przepowiadanie słowa Bożego nie istnieje bez kerygmatu.

Dynamizm wiary, jaki wyzwala w chrześcijaninie chrzest w Duchu Świętym, uzdalnia kaznodzieję do głoszenia słowa Bożego w mocy Ducha Świętego i uaktywnia w nim sferę kreatywności. Autentyczne natchnienie płynące do Ducha Świętego pomaga mu odnaleźć nowe znaczenia biblijnego tekstu, nowe obrazy i symbole Bożej obecności w świecie. Prowadzi to do bardziej adekwatnej aktualizacji Dobrej Nowiny w życiu słuchacza.

Odnowa charyzmatyczna przepowiadania słowa Bożego wskazuje na konieczność pogłębienia świadomości kaznodziejów co do znaczenia charyzmatów słowa oraz zaprasza do większej otwartości na nie.

54 Por. J. Kudasiewicz, Odkrywanie Ducha Świętego, dz. cyt., s. 415.

55 Por. Jan Paweł II, List apostolski „Dies Domini” o świętowaniu niedzieli, Wrocław 1999, nr 28.

56 Por. J. H. Prado Flores, Jak ewangelizować ochrzczonych, Poznań 2016, s. 99-116. 


\section{Summary}

\section{Przepowiadanie jako charyzmat. Chrzest w Duchu Świętym a głoszenie słowa Bożego}

Soborowa i posoborowa odnowa Kościoła ukazała, że w jego sercu wielkie znaczenie mają liczne dary charyzmatyczne. Wydarzenie pentekostalne w Duquesne (USA) w 1967 roku i związane z nim powstanie Katolickiej Odnowy Charyzmatycznej, zdynamizowało ruchy ewangelizacyjne w Kościele zakorzenione w doświadczeniu chrztu w Duchu Świętym. Ma ono do dziś wpływ na rozwój i recepcję posługi słowa Bożego w Kościele. Chrzest w Duchu Świętym mocno formuje profil duchowy kaznodziei, a co za tym idzie oddziałuje na jego duchowość. Duch Święty udziela też licznych charyzmatów słowa, np. proroctwa i nauczania, udziela kaznodziei nadprzyrodzonej mocy głoszenia, co ma niebagatelne znaczenie dla całokształtu przepowiadania słowa Bożego. Na pierwsze miejsce wysuwa się głoszenie kerygmatu i osobiste świadectwo kaznodziei.

Słowa kluczowe: głoszenie słowa Bożego, przepowiadanie charyzmatyczne, przepowiadanie prorockie, duchowość kaznodziei, charyzmat nauczania

Preaching as a Charisma. The Baptism in the Holy Spirit and the Proclamation of the Word of God

The Second Vatican Conciliar and Postonciliar renewal of the Church demonstrated that, in its heart, many charismatic gifts are of great importance. The Pentecostal event in Duquesne (USA) in 1967 and the related establishment of the Catholic Charismatic Renewal, made the evangelizing movements rooted in the experience of baptism in the Holy Spirit in the Church more dynamic. Until today it has an impact on the development and reception of the ministry of the word of God in the Church. Baptism in the Holy Spirit strongly forms the spiritual profile of the preacher, and thus affects his spirituality. The Holy Spirit also gives many charisms of the word, such as prophecy and teaching, gives the preacher the supernatural power of preaching, which is of great importance for the whole preaching of the word of God. The preaching of the kerygma and the personal testimony of the preacher come to the first place.

Keywords: proclamation of the word of God, charismatic preaching, prophetic preaching, preacher spirituality, teaching charism 


\section{Bibliografia}

Benedykt XVI, Rozważanie na „Anioł Pański”, 11 maja 2008, https://opoka.org.pl/ biblioteka/W/WP/benedykt_xvi/modlitwy/ap_11052008.html (10.09.2018).

Bigiel M., Jezus chrzci Duchem Świętym, Łódź 1997.

Bohren R., Predigtlehre, München 1971.

Cantalamessa R., Pieśń Ducha Świętego. Rozważania na temat „Veni Creator”, Warszawa 2003.

Cantalamessa R., Raduj się, Córko Syjonu. Tajemnica Bożego Narodzenia, Warszawa 1995.

Cantalamessa R., Tajemnica Pięćdziesiątnicy, Wrocław 2002.

Chlondowski W. P., Spetniona obietnica. Kim jest i jak działa Duch Święty?, Cieszyn 2016.

Chrostowski, W., Biblijna nauka o Duchu Świętym, w: Jesteśmy napełnieni Duchem Świętym: zeszyt liturgiczny, red. J. Bartoszek, R. Chromy, K. Piechaczek, Katowice 2017 (Program duszpasterski Kościoła w Polsce na Rok 2017-2018, 4).

Congar, Y., Słowo i Tchnienie, Kraków 2018.

Faricy, R., The Baptism in the Holy Spirit: My experience and a conclusion, w: Charism and the Charismatic Renewel in the Catholic Church. International Colloquium (Rome, 3-6 April 2008), Vatican 2015, s. 77.

Franciszek, Adhortacja apostolska „Evangelii gaudium” o głoszeniu Ewangelii we wspótczesnym świecie (2013), wyd. 2, Kraków 2014.

Jan Paweł II, List apostolski „Dies Domini” o świętowaniu niedzieli, Wrocław 1999.

Kongregacja Nauki Wiary, List „Iuvenescit Ecclesia” na temat relacji między darami hierarchicznymi a charyzmatycznymi dla życia i misji Kościoła, Rzym 2016, https://episkopat.pl/en/relacja-miedzy-darami-hierarchicznymi-a-charyzmatycznymi-list-kongregacji-nauki-wiary (10.09.2018).

Kudasiewicz J., Duch Święty i Jego dary, Kraków 2008.

Kudasiewicz J., Odkrywanie Ducha Świętego. Medytacje biblijne, Kielce 1998.

McDonnell K., Montague G. T., Inicjacja chrześcijańska a chrzest w Duchu Świętym. Świadectwo z pierwszych ośmiu wieków, Kraków 1997.

Międzynarodowe Służby Katolickiej Odnowy Charyzmatycznej. Komisja Doktrynalna, Chrzest w Duchu Świętym, Kraków 2014.

Mühlen, H., Kirche wächst von innen. Weg zu einer glaubensgeschichtlich neuen Gestalt der Kirche, Paderborn 1995.

Odnowa Charyzmatyczna. Wskazania teologiczne i duszpasterskie, I. Dokument z Malines, red. L. J. Suenens, Kraków 2006.

Prado Flores, J. H., Jak ewangelizować ochrzczonych, Poznań 2016.

Sionek, A., Charyzmaty. Aktywna obecność Boga w Kościele, Kraków 2017.

Sionek, A., Napetniajcie się Duchem! Wspótczesny etos Nowej Ewangelizacji, Kraków 2018.

Sobór Watykański II, Konstytucja dogmatyczna o Kościele „Lumen gentium”, w: Konstytucje. Dekrety. Deklaracje, Poznań 2002, s. 104-166.

Tomasz z Akwinu, Komentarz do Ewangelii Jana, XV, nr 2061 tłum. T. Bartoś, Kęty 2002. 